\title{
Effect of penicillamine on complement in vitro and in vivo
}

\author{
O. J. MELLBYE AND E. MUNTHE
}

From the Institute of Immunology and Rheumatology, Rikshospitalet University Hospital, and Oslo Sanitetsforenings Rheumatism Hospital, Oslo, Norway

SUMMARY In most normal human sera the addition of penicillamine to a final concentration of $0.2 \mathrm{mmol} / \mathrm{l}$ and subsequent dialysis caused a slight reduction in serum haemolytic complement $\left(\mathrm{CH}_{50}\right)$. At $200 \mathrm{mmol} / \mathrm{l}, \mathrm{CH}_{50}$ activity was no longer demonstrable. Even higher concentrations of penicillamine were needed to inhibit the ability of immunoglobulin to fix complement to preformed or forming immune complexes. This indicated that the reduction of $\mathrm{CH}_{50}$ observed in serum was due to an effect on the complement factors. In vivo, a dose of $240 \mathrm{mg}$ penicillamine caused a slight transient reduction in $\mathrm{CH}_{50}$ in rabbit serum, while $1000 \mathrm{mg}$ penicillamine had no effect on serum $\mathrm{CH}_{50}$ in patients with rheumatoid arthritis. In arthritis patients there was, however, some evidence for removal of complement deposits in synovial tissue during penicillamine treatment. Since it is theoretically possible that concentrations high enough to cause reduction of complement activity can be achieved locally in synovial tissue, the effect on complement may be one of the mechanisms by which penicillamine exerts its effect in rheumatoid arthritis.

The effect of penicillamine in rheumatoid arthritis (RA) is no longer believed to be due to its splitting effect on IgM rheumatoid factors (Jaffe, 1970). However, if we assume that immune complex formation with subsequent complement fixation and activation are pathogenetic factors in RA (Zvaifler, 1973), there are several other immunological mechanisms which may explain the activity of penicillamine in this disease. One is that it acts as a general immunosuppressive agent. There is some experimental and clinical support for this (Altman and Tobin, 1965; Hübner and Gengozian, 1965; Bluestone and Goldberg, 1973), though in other studies no immunosuppressive effect (Liyanage and Currey, 1972) or even an enhanced immune response has been found (Tobin and Altman, 1964; Herrlinger et al., 1975; Mellbye, 1977).

A second explanation may be that penicillamine, by forming mixed disulphides with proteins (Jellum and Skrede, 1977), inhibits complement binding to immunoglobulins in immune complexes and/or subsequent complement activation. Other disulphidereducing agents have been shown to inhibit complement fixation to IgG (Wiedermann et al., 1963;

Accepted for publication February 5, 1977

Correspondence to Dr. O. J. Mellbye, Institute of Immunology and Rheumatology, Rikshospitalet University Hospital, F. Qvams gate 1, Oslo 1, Norway
Schur and Christian, 1964). It is also known that complement activation depends on a series of enzymatic steps, and it seems possible that one or more of these might be blocked by sulphydryl groupcontaining agents forming mixed disulphides. Therefore, the purpose of the present investigation was to test the effect of penicillamine on complement in vitro and in vivo.

\section{Materials and methods}

PENICILLAMINE

For the in vitro studies and the animal experiments D-penicillamine and $\mathrm{N}$-acetyl-DL-penicillamine were obtained from Sigma Chemical Company (St. Louis, Mo., USA). For treatment of patients, D-penicillamine was given as Cuprimine (MSD, Rahway, N.J., USA).

TITRATION OF HAEMOLYTIC COMPLEMENT ACTIVITY $\left(\mathrm{CH}_{50}\right)$

This was performed as described by Mayer (1967).

TREATMENT OF SERA IN VITRO

Human serum was obtained from healthy blood donors and laboratory personnel. The sera were either tested immediately or stored at $-70^{\circ} \mathrm{C}$ until testing. Treatment with penicillamine was performed 
by adding one volume of penicillamine solution in veronal-buffered saline (VBS), $\mathrm{pH} 7 \cdot 2$, to one volume of serum and incubating the mixture at $37^{\circ} \mathrm{C}$ for 30 minutes. In the initial experiments the mixture was then dialysed for 3 hours at room temperature against iodoacetamide in $15 \%$ molar excess, followed by dialysis overnight at $4^{\circ} \mathrm{C}$ against VBS. In later experiments dialysis against iodoacetamide was omitted.

Treatment of the rabbit antiserum to sheep red cells (amboceptor) with penicillamine was performed as described for human sera, except that treatment with iodoacetamide was omitted and dialysis against VBS was omitted in some of the experiments.

\section{TREATMENT OF IMMUNE COMPLEXES}

Immune complexes, consisting of rabbit anti-BSA (bovine serum albumin) and its antigen, were produced at equivalence on the basis of a quantitative precipitation curve. The precipitates were washed three times and suspended in phosphate-buffered saline (PBS), pH 7·4. Titration experiments were performed to find the lowest amount of precipitates which gave a clear inhibition of $\mathrm{CH}_{50}$ in the test system used. This was done to obtain maximum sensitivity for detection of inhibition of the complement-fixing ability of the precipitates. The precipitate was added to a solution of penicillamine, and after 1 hour's incubation at $37^{\circ} \mathrm{C}$, the precipitates were washed three times and resuspended in PBS.

\section{TREATMENT OF RABBITS}

Black and white land rabbits, weighing approximately $2.5 \mathrm{~kg}$, were given intramuscular injections of penicillamine. Blood samples were obtained from marginal ear veins before the injection and at intervals afterwards.

TREATMENT OF PATIENTS

Patients with classical or definite RA, according to the criteria by the American Rheumatism Association (McEwen, 1972) were tested. To examine the effect on $\mathrm{CH}_{50}$ in serum, $1000 \mathrm{mg}$ D-penicillamine was given orally in one dose to patients who had either not received the drug before or had been taken off the drug for at least 3 days. Blood was obtained immediately before administration and at intervals afterwards.

To test the effect on complement deposition in synovial tissue, specimens obtained by synovectomy were examined by immunofluorescence technique. Immediately after surgery the tissue was cut into small pieces, washed in PBS, embedded in OCT Tissue-Tec, and deep-frozen in dry ice/acetone before cutting in a cryostat. Frozen sections were stained with fluoresceinated rabbit antisera against human immunoglobulins, complement factor $\mathrm{C} 3 \mathrm{P}$ and fibrinogen as previously described (Munthe an $\$$ Natvig, 1972). Tissue specimens were from sym metrical joints in 3 cases, both joints being af approximately the same clinical and radiologicat stages. In all joints the arthritis was active and of long duration (more than 6 months), and in af cases there was a clear indication for synovectomy? This was performed on one side just before the patient started treatment with penicillamine (up t $\vec{\delta}$ a maximum of $750 \mathrm{mg}$ daily after 3 months), and synovectomy on the contralateral joint was usually performed after 3 months' treatment. In some cases tissues were examined only after treatment.

QUANTITATION OF C3 AND C4, AND DETECTIO OF C3 CONVERSION PRODUCTS

Quantitation was performed by radial diffusion if gel analysis (Mancini et al., 1965), and conversion of C3 was tested for by crossed immunoelectrophoresis against anti-C3 (Laurell, 1965).

\section{Results}

EFFECT ON COMPLEMENT FIXATION TO IMMUNE COMPLEXES IN VITRO

To test the effect of penicillamine on complement fixation to Ig before or during immune comple formation, rabbit antiserum to sheep red cells was treated with penicillamine before sensitization of sheep red cells for $\mathrm{CH}_{50}$ testing. In two experiments the treated antiserum was dialysed against VBS t $\vec{\delta}$ remove excess penicillamine before sensitization, while in three experiments this was omitted to avoid a possible reversal of the effect before the interaction. with the antigen on the sheep red cells. In all cases an inhibiting effect of penicillamine on complement fixation was observed only when the concentratio was as high as $200 \mathrm{mmol} / \mathrm{l}$. Two examples are shown in Fig. 1.

To test the effect on preformed immune complexes? precipitates made from rabbbit antiserum to BSA and its antigen were used. After incubation witp varying concentrations of penicillamine, the abilit立. of the precipitates to fix complement, and therebo reduce $\mathbf{C H}_{50}$ in normal human sera, was neutralized in one serum when the concentration was as high as $20 \mathrm{mmol} / \mathrm{l}$. In three other sera no significant effect was seen even when the concentration of penicis lamine was increased to $200 \mathrm{mmol} / \mathrm{l}$. Two exampleq are included in Fig. 1.

EFFECT ON HAEMOLYTIC COMPLEMENT ACTIVITY IN SERUM IN VITRO

When human sera were incubated with varyin $\mathbb{\Phi}$ concentrations of penicillamine, there was a constand 
dose-dependent decrease of $\mathrm{CH}_{50}$ in the reaction mixture. In five of the six sera tested there was a reduction of at least $15 \%$ in $\mathbf{C H}_{50}$ when the final

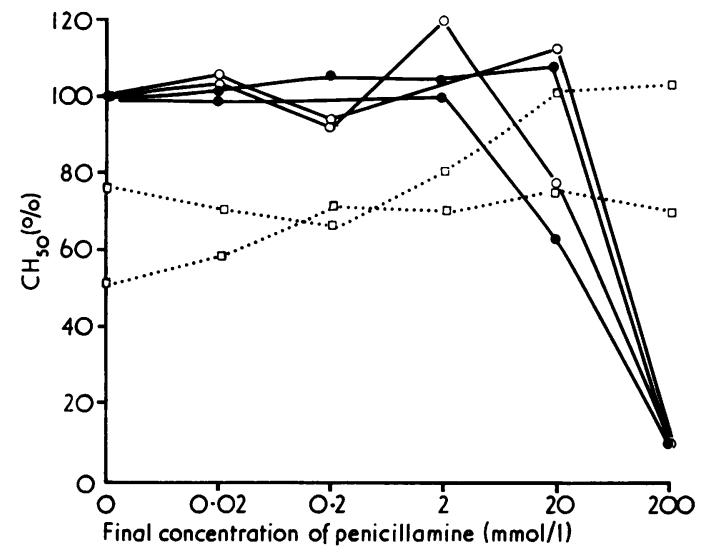

Fig. 1 Effect of penicillamine on ability of immune complexes to fix complement in vitro. Solid lines show $\mathrm{CH}_{50}$ testing of normal human sera by sheep red cells sensitized with rabbit antiserum treated with $\mathrm{D}-$ penicillamine and either dialysed ( $\bullet$ ) or not dialysed (o) after treatment. Dotted lines show $\mathrm{CH}_{50}$ in sera after addition of BSA-anti-BSA (bovine serum albumin) precipitates treated with penicillamine. $\mathrm{CH}_{50}$ values are given as percentage of value with no penicillamine or precipitates added. Values below the lower limit of detection in the test system, $20 \%$, are plotted as $10 \%$.

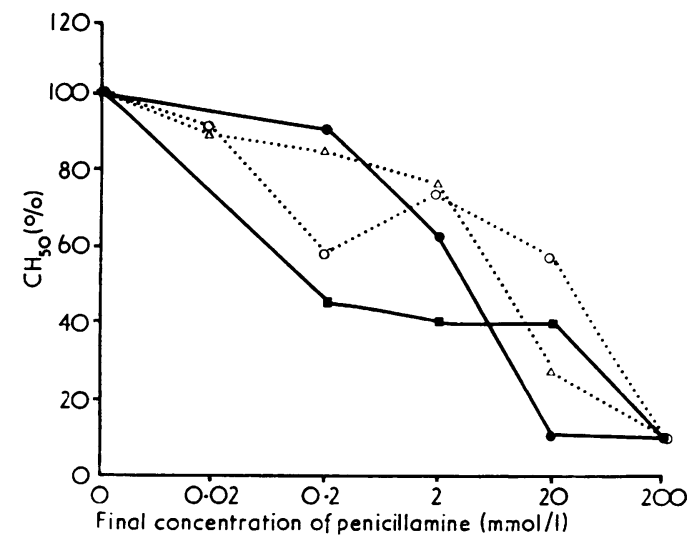

Fig. $2 \mathrm{CH}_{50}$ in serum after addition of penicillamine in vitro. Solid lines show $\mathrm{CH}_{50}$ in one serum treated with $\mathrm{D}$-penicillamine (๑) or DL-penicillamine ( $\mathrm{G})$, and dialysed against veronal-buffered saline (VBS). Dotted lines show $\mathrm{CH}_{50}$ in another serum treated with $\mathrm{D}$-penicillamine and either treated with iodoacetamide $(\Delta)$ or not treated (o) before dialysis against VBS. Otherwise as for Fig. 1. concentration of penicillamine was $0.2 \mathrm{mmol} / \mathrm{l}$. At a concentration of $200 \mathrm{mmol} / \mathrm{l}$ the activity was in all cases below the lower limit of detection in our test system, corresponding to a decrease of at least $80 \%$.

As shown in Fig. 2, there was no significant difference between the inhibiting effect of $D$ penicillamine and DL-acetyl-penicillamine. In these experiments the reaction mixture was treated with iodoacetamide after penicillamine to avoid possible reoxidation of reduced sulphydryl groups. However, as also shown in Fig. 2, there seemed to be no difference between sera treated with iodoacetamide and sera dialysed against PBS only.

The concentration of $\mathrm{C} 3$ and $\mathrm{C} 4$ were tested in four sera before and after treatment with D-penicillamine in a concentration of $200 \mathrm{mmol} / \mathrm{l}$. No significant change was observed. Nor was any conversion of $\mathrm{C} 3$ found by crossed immunoelectrophoresis.

\section{EFFECT ON RABBIT SERUM COMPLEMENT ACTIVITY IN VIVO}

$240 \mathrm{mg}$ D-penicillamine was given intramuscularly to 5 rabbits and serum $\mathrm{CH}_{50}$ tested at intervals afterwards. In 2 rabbits the experiment was repeated after 5 days. The results of the seven experiments (Fig. 3) showed a great variation, but at 4 and 6 hours after administration, complement activity was reduced in all cases. Control experiments in 2 rabbits with injection of PBS alone indicated that the reduced activity seen after penicillamine was not due to the injection itself or to physiological diurnal variation in the animals.

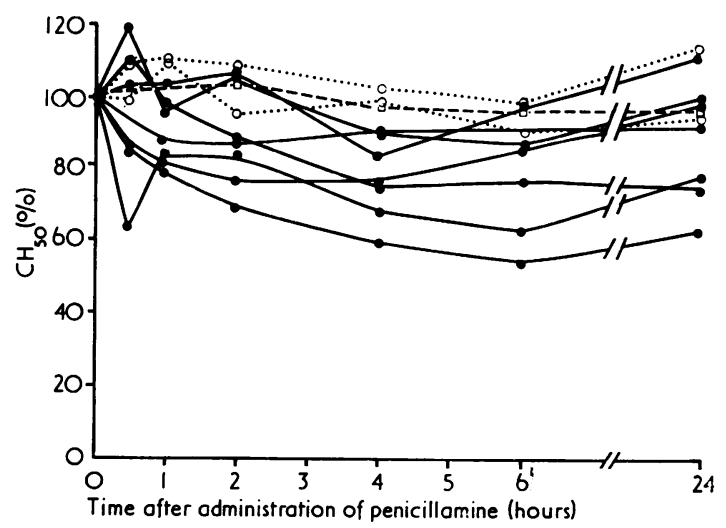

Fig. $3 \mathrm{CH}_{50}$ in serum after in vivo administration of D-penicillamine. Solid lines show the results in rabbits; broken line the result in 1 patient with $R A$; dotted lines the results in control rabbits given phosphate-buffered saline only. 
EFFECT ON HUMAN SERUM COMPLEMENT IN PATIENTS WITH RA

Four patients with RA, 2 of whom had not been treated with penicillamine and 2 who had been taken off the drug for 3 days, were given $1000 \mathrm{mg}$ penicillamine orally in one dose. $\mathrm{CH}_{50}$ was tested just before the drug was given and at intervals afterwards. No significant reduction of $\mathrm{CH}_{50}$ was observed. On the contrary, in one of the patients who had not received the drug previously there was a slight increase in $\mathrm{CH}_{50}$. One typical example is included in Fig. 3.

EFFECT ON DEPOSITION OF COMPLEMENT IN RHEUMATOID SYNOVIAL TISSUE

Before treatment with penicillamine synovial tissues examined by immunofluorescence technique usually showed large amounts of granular and/or lumpy deposits of immunoglobulins, complement factor C3, and fibrin. When tissues removed after 3 months of penicillamine treatment were examined and compared with the specimens taken before treatment,

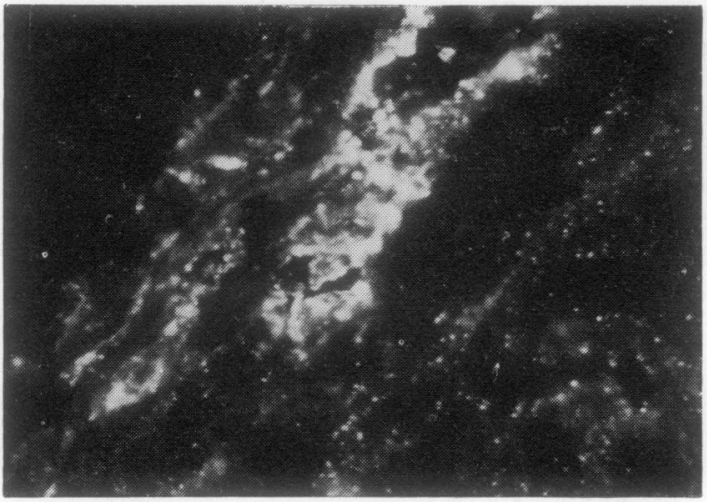

(a) there appeared to be an overall, small reduction $\emptyset \mathrm{f}$ the immunoglobulin content (Table). However, the amount of immunoglobulins varied consideraby from one area to another in the same section.

One patient (Case 6) did not respond clinically the treatment, and also had the largest amount $\overline{\sigma o}$ immunoglobulins in the tissues when examined af 6 months' treatment. Deposits of fibrin in the tissuess showed no significant changes after the 3-monfth observation period. The only clear difference wasca reduction in staining for $\mathrm{C} 3$ after treatment. The changes were particularly striking in Cases 1 and (Table). As shown in Figs. $4 a$ and $b$, the deposition of IgG was about the same before and after pericillamine, but the staining for C3 was cleany reduced (Figs. 5a, b).

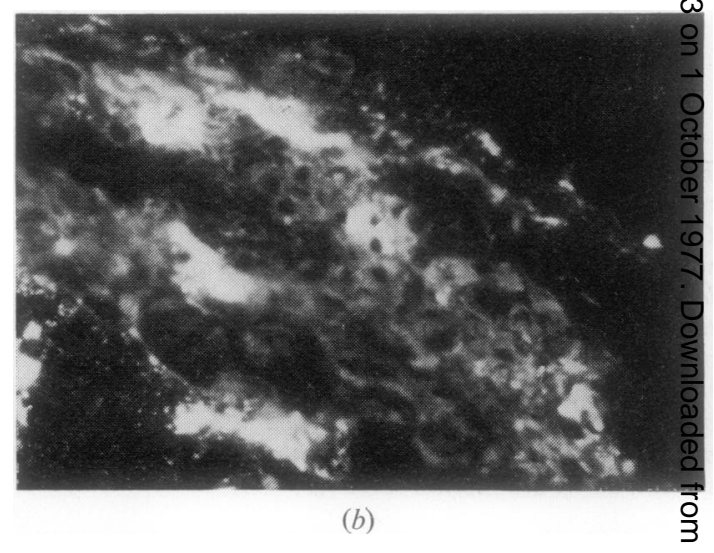

Fig. 4 (a) Synovial membrane from Case 1 (left wrist removed before penicillamine treatment and stained for $\stackrel{.}{-}$ IgG. $\times 200$. (b) Synovial membrane from right wrist of Case 1 , removed after 3 months' penicillamine treatmento and stained for $\operatorname{Ig} G$, showing no significant difference from $(a) . \times 200$.

Table Immunofluorescence microscopical observations before and after penicillamine treatment

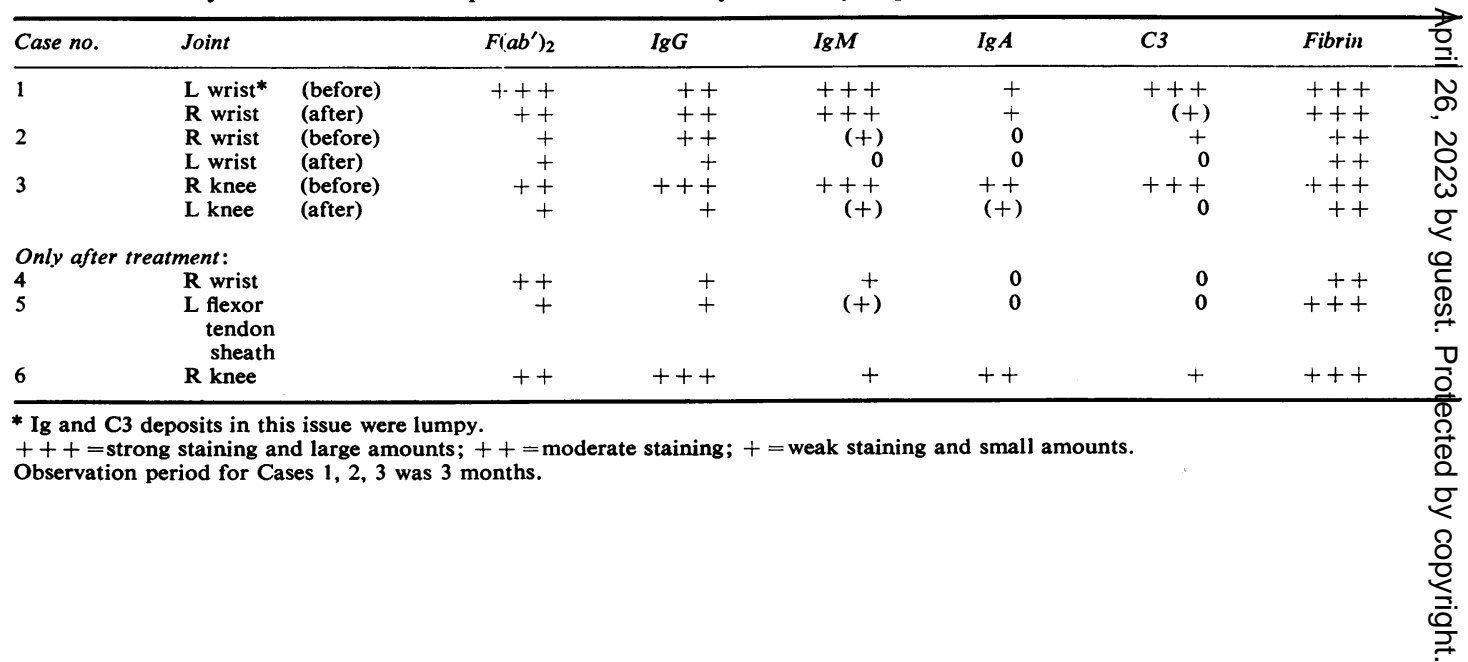




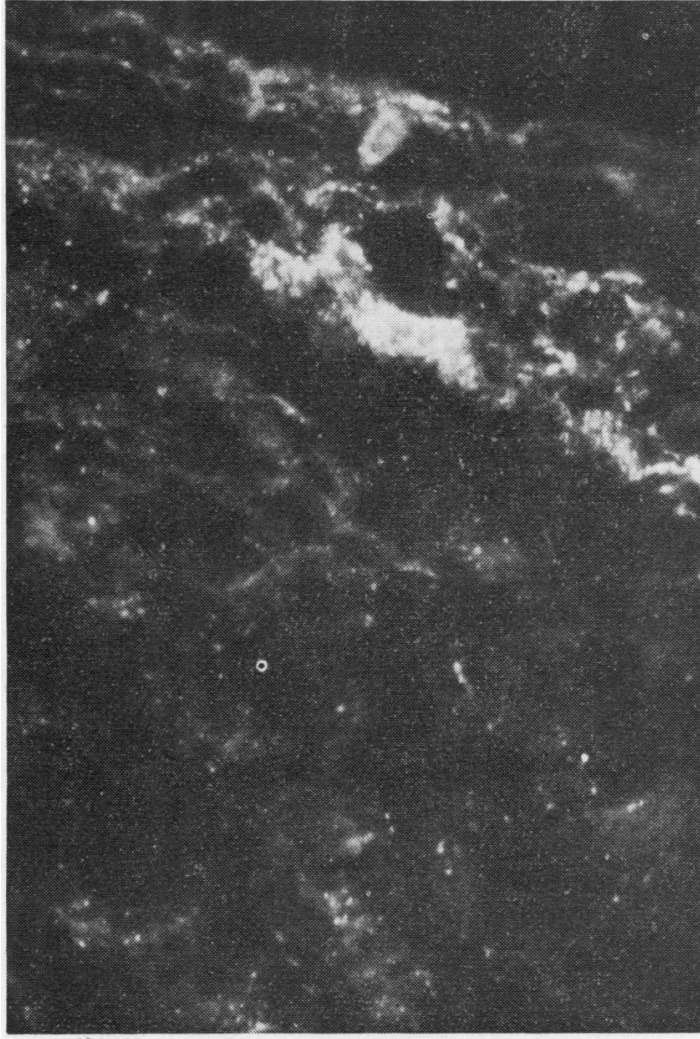

(a)

\section{Discussion}

Our investigation showed that in vitro, penicillamine causes a dose-dependent inhibition of $\mathrm{CH}_{50}$ activity in serum. Using the same concentrations of penicillamine, there is little or no effect on the ability of immunoglobulins to fix complement to preformed or forming immune complexes. In vivo, a single relatively high dose of penicillamine caused a slight fall in serum complement activity in rabbits, but there was no similar effect in patients with RA. In RA patients there was, however, some evidence for removal of complement deposits in synovial tissue during penicillamine treatment.

It seems unlikely that the concentrations of penicillamine necessary to get a pronounced effect on complement in vitro is reached in vivo in blood in clinical situations. However, the concentration of penicillamine in synovial tissue is probably much higher than in serum (Ruiz-Torres, 1974), possibly as high as between 0.2 and $1.0 \mathrm{mmol} / 1$ (J. Aaseth, personal communication, 1976). Thus, the in vitro experiments may elucidate in vivo processes.

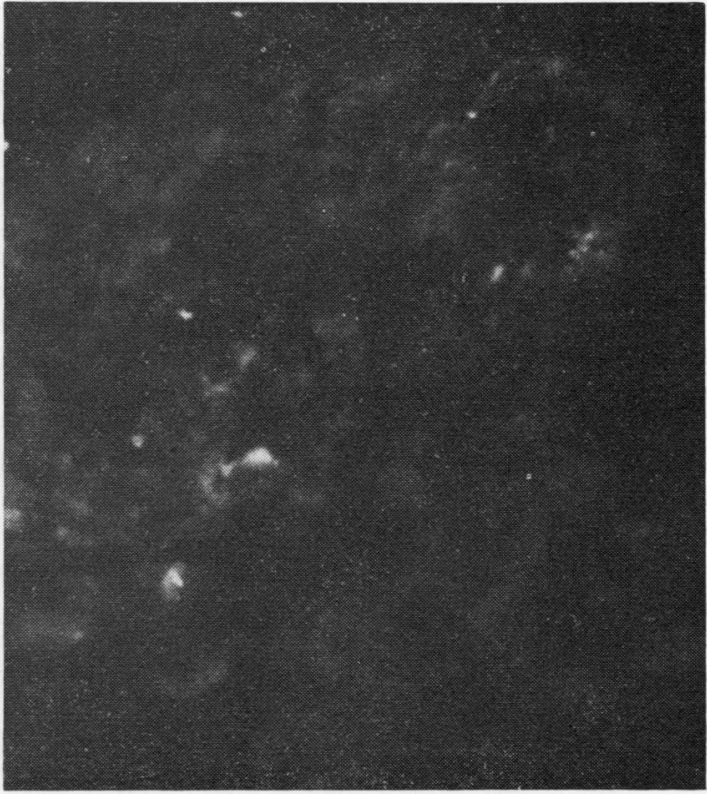

(b)

Fig. 5 (a) Same membrane as in 4(a), but stained for C3. (b) Same membrane as in 4(b), but stained for C3. Less staining than seen before penicillamine. $\times 200$.

It has previously been stated that penicillamine does not inhibit $\mathrm{CH}_{50}$ activity in vitro, since a reduction of only $15 \%$ was obtained with the highest concentration of penicillamine used, $2.7 \mathrm{mmol} / 1$ (Chwalińska-Sadowska and Baum, 1977). This result agrees with our own observations, and we had to increase the concentration to get a more pronounced inhibition.

The dose given in the rabbit in vivo experiments, approximately $80 \mathrm{mg} / \mathrm{kg}$, may seem high when compared with the usual dose given to RA patients, usually up to $20 \mathrm{mg} / \mathrm{kg}$. However, since the evaluation of the effect of drugs in various species should take into consideration the difference in metabolic rate (Berenbaum, 1975), these two dosages should be comparable.

Even if the concentration of penicillamine in vivo is high enough to inactivate complement, this does not necessarily mean that it has a beneficial effect on rheumatoid inflammation. However, there are experimental animal models which resemble RA in man and where decomplementation has been shown to prevent the development of the disease process (Cochrane, 1968).

It may be argued that since penicillamine is a chelating agent, able to bind divalent ions, the observed effect on $\mathrm{CH}_{50}$ activity may be due to 
removal of calcium and magnesium ions needed for complement activity. This can be excluded since almost all samples were dialysed against buffer containing optimal concentrations of these ions before testing for $\mathrm{CH}_{50}$. The possibliity that the effect of penicillamine was due to a splitting effect on the antiserum to sheep red cells, the amboceptor, which might have interfered with the test system for $\mathrm{CH}_{50}$ activity, was also excluded.

It is theoretically possible that the observed effect of penicillamine on $\mathrm{CH}_{50}$ is not due to an effect on the complement factors themselves but is caused by formation of complement-binding complexes of unknown composition. The finding of unchanged concentrations of $\mathrm{C} 3$ and $\mathrm{C} 4$, measured as protein antigens, and lack of $\mathrm{C} 3$ conversion products after incubation with penicillamine argues against this possibility.

The reduction in $\mathrm{C} 3$ deposition in synovial tissue after penicillamine treatment in patients with RA may be due to a direct effect of penicillamine on complement or the complement-binding ability of complexes in the tissue, though it may only be a secondary result of improvement of the synovitis. Moreover, there are several methodological difficulties involved in comparing immunofluorescence results in tissues obtained at different times.

It remains to be shown that penicillamine has a direct inhibiting effect on complement in rheumatoid synovial tissue. Taking into consideration all the various in vitro and in vivo effects of penicillamine (Munthe, 1977), it is likely that an inhibition of complement may be only one of several mechanisms for the therapeutic effect of this drug in RA.

We thank Dr. J. Teigland for providing synovial tissue, Miss Zaib-un-Nisa for excellent technical assistance, and the Norwegian Women's Public Health Organization for financial support.

\section{References}

Altman, K., and Tobin, M. S. (1965). Suppression of the primary immune response induced by $D-L$ penicillamine. Proceedings of the Society for Experimental Biology and Medicine, 118, 554-557.

Berenbaum, M. C. (1975). The clinical pharmacology of immunosuppressive agents. Clinical Aspects of Immunology, 3rd ed., pp. 689-758. Ed. by P. G. H. Gell, R. R. A. Coombs, and P. J. Lachmann. Blackwell, Oxford.

Bluestone, R., and Goldberg, L. S. (1973). Effect of Dpenicillamine on serum immunoglobulins and rheumatoid factor. Annals of the Rheumatic Diseases, 32, 50-52.

Chwalinska-Sadowska, H., and Baum, J. (1977). The effect of D-penicillamine on polymorphonuclear leukocyte function: chemotaxis and phagocytosis. Penicillamine Research in Rheumatoid Disease, pp. 64-67. Ed. by E. Munthe. Fabritius/MSD Norway, Oslo.
Cochrane, C. G. (1968). Immunologic tissue injury mediated므. by neutrophilic leukocytes. Advances in Immunology, 9 , ? 97-162.

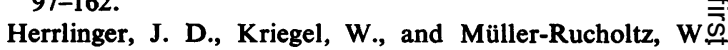
(1975). Wirkung von D-penicillamin auf die humoraleo Primärantwort. Klinische Wochenschrift, 53, 831-833.

Hübner, K. F., and Gengozian, N. (1965). Depression of the primary immune response by dl-penicillamine. Proceeding of the Society for Experimental Biology and Medicine, 118, 561-565.

Jaffe, I. A. (1970). The treatment of rheumatoid arthritis and necrotizing vasculitis with penicillamine. Arthritis and Rheumatism, 13, 436-443.

Jellum, E., and Skrede, S. (1977). Biological aspects of thiol $\vec{\omega}$ disulphide reactions during treatment with penicillamine? Penicillamine Research in Rheumatoid Disease, pp. 68-79. Ed. by E. Munthe. Fabritius/MSD Norway, Oslo.

Laurell, C.-B. (1965). Antigen-antibody crossed electro. phoresis. Analytical Biochemistry, 10, 358-361.

Liyanage, S. P., and Currey, H. L. F. (1972). Failure of orate D-penicillamine to modify adjuvant arthritis or immunew response in the rat. Annals of the Rheumatic Diseases, 31, 521.

McEwen, C. (1972). The diagnosis and differential diagnosis of rheumatoid arthritis. Arthritis and Allied Conditions, $\mathrm{S}$ 8th ed., pp. 403-418. Ed. by J. L. Hollander and D. JO McCarty. Lea and Febiger, Philadelphia.

Mancini, G., Carbonara, A. O., and Heremans, J. F. (1965) Immunochemical quantitation of antigens by single radiake diffusion. Immunochemistry, 2, 235-254.

Mayer, M. M. (1967). Hemolytic assay of complement Experimental Immunochemistry, 2nd ed., pp. 133-240. Ed by E. A. Kabat and M. M. Mayer. Thomas, Springfield Illinois.

Mellbye, O. J. (1977). Effect of penicillamine on the humorap immune response, aggregation of IgG and complement activity. Penicillamine Research in Rheumatoid Disease, pp. 119-125. Ed. by E. Munthe. Fabritius/MSD Norway Oslo.

Munthe, E. (1977). (Editor.) Penicillamine Research in Rheumatoid Disease. Fabritius/MSD Norway, Oslo.

Munthe, E., and Natvig, J. B. (1972). Immunoglobulin classes, subclasses and complexes of IgG rheumatoid factorin in rheumatoid plasma cells. Clinical and Experimenta? Immunology, 12, 55-70.

Ruiz-Torres, A. (1974). Zur Pharmakokinetik und zum? Stoffwechsel von D- und L-penicillamin. II. Mitteilung Verteilung von $\mathrm{D}$ - und L-penicillamin- ${ }^{14} \mathrm{C}$ in Organismusder Ratte nach peroraler Verabvolgung. ArzneimittelForschung, 24, 1043-1046.

Schur, P. H., and Christian, G. D. (1964). The role of disulfide bonds in the complement-fixing and precipitating properties of $7 \mathrm{~S}$ rabbit and sheep antibodies. Journal of Experimental Medicine, 120, 531-545.

Tobin, M. S., and Altman, K. (1964). Accelerated immunê response induced by D-L penicillamine. Proceedings of the Society for Experimental Biclogy and Medicine, 115 225-228.

Wiedermann, G., Miescher, P. A., and Franklin, E. C. (1963) Effect of mercaptoethanol on complement binding ability of human 7S gammaglobulin. Proceedings of the Society for $\mathbb{D}$ Experimental Biology and Medicine, 113, 609-613.

Zvaifler, N. (1973). The immunopathology of joint inflam- $\square$ mation in rheumatoid arthritis. Advances in Immunology, 16, 265-336. 